\title{
Ground-foraging ants (Hymenoptera: Formicidae) and rainfall effect on pitfall trapping in a deciduous thorn woodland (Caatinga), Northeastern Brazil
}

\author{
Francyregis A. Nunes ${ }^{1,2}$, Glauco B. Martins Segundo ${ }^{1,2}$, Yuri B. Vasconcelos ${ }^{2}$, Raul Azevedo ${ }^{2}$ \\ \& Yves Quinet ${ }^{1,2}$ \\ 1. Programa de Pós-graduação em Ecologia e Recursos Naturais, Departamento de Biologia, Universidade Federal do \\ Ceará, Campus do Pici - Bloco 906 - 60455-760 Fortaleza, CE, Brazil; francyregis@yahoo.com.br, \\ glaucobmsegundo@hotmail.com, yvesq@terra.com.br \\ 2. Laboratório de Entomologia, Instituto Superior de Ciências Biomédicas, Universidade Estadual do Ceará, Av. \\ Paranjana, 1700,60740-000 Fortaleza-CE - Brazil; yuribvasconcelos@hotmail.com, raulbiologo@gmail.com
}

Received 22-XI-2010. Corrected 15-IV-2011. Accepted 16-V-2011.

\begin{abstract}
The semi-arid Caatinga is the fourth largest biome of Brazil, which biota still remains one of the most poorly known, especially with regard to invertebrate groups. In this study, a ground-foraging ant assemblage was surveyed during one year and the effect of rainfall on pitfall trapping was assessed. The study was performed in an area located in the municipality of Pentecoste ( $\left.3^{\circ} 48^{\prime} \mathrm{S}-39^{\circ} 20^{\prime} \mathrm{W}\right)$, in the State of Ceará. A $200 \mathrm{~m}$ transect with 20 equidistant sampling points was established. Transect sampling was performed once a month during 12 months, over the period August 2008-August 2009. At each sampling point, a pitfall trap partially filled with a mixture of ethanol and monoethylene glycol was placed at the beginning of each month and remained in the field for seven days. 39 species belonging to six subfamilies and 19 genera, plus two unidentified species, were collected, with Pheidole (10 spp.) and Camponotus ( $8 \mathrm{spp}$.) being the taxa with the most species. 23 species were frequent, being found in more than $50 \%$ of the 12 transect samplings. Five species had an intermediate frequency (25 to 50\%), while 13 were relatively infrequent (less than 25\%). Most of the species (22) showed low occurrence, being found in less than $10 \%$ of the 240 samples (20 samples each month, during 12 months). Only five species were collected in more than $50 \%$ of the samples, those species being also responsible for most of the total abundance (number of captured individuals of all species) observed each month. The speciesaccumulation curves (observed and estimated) indicated that sampling sufficiency was attained, and that about $92 \%$ of the estimated ground-foraging ant fauna had been collected. 40 and 29 species were collected in the dry and rainy season, respectively, with monthly species richness ranging from 13 to 28 . The total ant abundance showed a drastic decrease during the rainy season, and a negative linear correlation was found between rainfall and total ant abundance $\left(\mathrm{R}^{2}=0.68\right)$. A similar negative linear correlation was found for species occurrences against rainfall $\left(\mathrm{R}^{2}=0.71\right)$, and for mean number of species per pitfall trap against rainfall $\left(\mathrm{R}^{2}=0.71\right)$. However, some species showed equal abundance, occurrence and mean number of individuals per pitfall trap in both seasons, while others showed a much higher abundance and occurrence during the rainy season. Pitfall trapping as a method to sample ground-foraging ant assemblage of the Caatinga biome and potential factors responsible for lower pitfall trap performance during rainy season are discussed. Rev. Biol. Trop. 59 (4): 1637-1650. Epub 2011 December 01.
\end{abstract}

Key words: semi-arid Caatinga, Formicidae, ground-foraging ant assemblage, pitfall trapping, rainfall.

Most of the semi-arid region of Northeastern Brazil, with a total area of about $750000 \mathrm{~km}^{2}$, is occupied by Caatinga, a regional name that refers to xerophytic, woody, thorny and deciduous vegetation with a seasonal herbaceous layer. It is the fourth largest Brazilian biome, after the Amazonian rain forest, the Cerrado and the Atlantic forest (Veloso et al. 1991, Pennington et al. 2000, Prado 2003, Costa et al. 2007). It is formed by a mosaic 
of vegetation types, ranging from seasonally dry forests with canopy trees, to scrub vegetation, depending on soil type, topography, and, above all, the amount of annual rainfall (Andrade-Lima 1981, IBGE 1993, Prado 2003). This is low in the Caatinga biome (less than $750 \mathrm{~mm} /$ year), concentrated in three consecutive months during the Southern hemisphere summer (November-June), and is prone to important inter-annual fluctuations (AndradeLima 1981, Prado 2003).

Until recently, the Caatinga was considered as a biome with poor species richness and very low level of endemism, especially with regard to its flora, which is believed to have a connection with the North of the South American Chaco (Rizzini 1963, 1997, Andrade-Lima 1982, Pennington et al. 2000). More systematic and thorough studies of Caatinga biodiversity in the last two decades have shown a different picture, with species richness much higher than that reported in earlier studies and at least equal to that observed in other dry forests around the world (Leal et al.2005). Furthermore, levels of endemism ranging from $3 \%$ to $57 \%$ have been found in important groups such as vascular plants (Prado 2003, Giulietti et al. 2004, Costa et al. 2007), fishes (Rosa et al. 2003), reptiles and amphibians (Rodrigues 2003), birds (Silva et al. 2003) and mammals (Oliveira et al. 2003). However, the survey of these groups is far from complete and was performed in limited areas of Caatinga, whose biota still remains one of the most poorly known in Brazil (Lewinsohn \& Prado 2002, Leal et al. 2005). Furthermore, studies of the main invertebrate groups of this biome are scarce (Lewinsohn \& Prado 2002, Martins et al. 2005).

Among invertebrates, ants are considered a keystone group in terrestrial animal communities for a number of reasons. The most prominent one is their abundance and ubiquity in almost all types of terrestrial habitats, especially in the tropics (Kaspari 2000, Dunn et al. 2010, Fisher 2010). The important and diverse functions they have at many different trophic levels, including many diverse interactions with other members of animal and plant communities, is another one (Holldobler \& Wilson 1990, Schultz \& McGlynn 2000, Passera \& Aron 2005, Ness et al. 2010). Furthermore, ants are recognized as useful tools for biodiversity evaluation and monitoring due to attributes such as permanent nests, quick response to environmental changes, relative ease of sampling and increasing availability of identification tools (Alonso \& Agosti 2000, Kaspari \& Majer 2000, Bestelmeyer et al. 2000, Underwood \& Fisher 2006).

In the Caatinga biome, studies of ant communities are still rare and somewhat limited in their scope. In one study, 61 species were collected at soil sardine baits placed in 70 parcels $(0.1$ hectare each) distributed in various Caatinga areas of two Northeastern Brazilian States (Alagoas and Sergipe) (Leal 2003). In other study performed in two Caatinga areas of the "Reserva Serra das Almas" (Ceará State), 24 species were collected at sardine baits placed on soil or vegetation (45 baits of each type in each area) and in soil pitfall traps (45 in each area) (Quinet \& Tavares 2005). One of them is a new, probably endemic, and not yet described, species of Blepharidatta, a sister group of Attini (fungus-growing ants), with only seven recognized species (Diniz et al. 1998, Silva 2007).

In open habitats or habitats with reduced structural complexity (low leaf cover litter for example), such as savannas or dry forests, pitfall trapping is one of the most recommended method for sampling epigaeic/ground-foraging ant species (Romero \& Jaffé 1989, Melbourne 1999, Parr \& Chown 2001, Delsinne et al. $2008,2010)$. It is also one of the most commonly employed and most efficient method for sampling litter-dwelling and ground-foraging ants in other environments like rain forest ecosystem, especially when it is combined with the Winkler extraction method (Agosti et al. 2000, Bestelmeyer et al. 2000, Delabie et al. 2000c).

However, pitfall trapping has some disadvantages: pitfall traps usually catch only a subset of an ant assemblage, mainly ground-dwelling and surface-active species, and interspecific 
differences in behaviors such as activity levels, deliberate avoidance of pitfall traps, or ability to escape from pitfall traps make ant species differentially susceptible to capture (Bestelmeyer et al. 2000). Furthermore, the number and composition of ants collected in pitfall traps can be affected by a number of factors like pitfall trap size, the type of preservative/killing agent used or even topographical, meteorological and edaphic variables of the sampled area (Gotteli et al. 2011).

The aim of the present work was to obtain a detailed description of a ground-foraging ant assemblage during one year in a Caatinga area using pitfall traps, and to test the effect of rainfall on pitfall trapping efficiency.

\section{MATERIALS AND METHODS}

Study site: The study was conducted in a relatively undisturbed area of deciduous thorny woodland vegetation (Caatinga) located in the municipality of Pentecoste (State of Ceará,

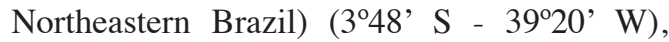
about 100 and $50 \mathrm{~km}$ from Fortaleza and the Atlantic coast, respectively. The vegetation in the study site had three main strata: a dense tree layer up to $8 \mathrm{~m}$, an open and low shrub layer, and a closed herbaceous layer.

Sampling methods: One line-transect within the study site was surveyed monthly during one year. The transect consisted of 20 sampling points separated by $10 \mathrm{~m}$ for a total extent of $200 \mathrm{~m}$. At each sampling point, a polyvinyl chloride (PVC) tube (14cm deep, $12.2 \mathrm{~cm}$ diameter) was placed in the soil and remained there for the whole sampling period (August 2008-August 2009). The PVC tubes served as sleeves to house the 20 pitfall traps $(13 \mathrm{~cm}$ deep, $12 \mathrm{~cm}$ diameter) used at the beginning of each month to sample the transect. Between the sampling events, the PVC tubes housed containers filled with locally collected soil. Such a procedure aimed at minimize disturbance due to monthly pitfall traps setting and removing. A polystyrene cover with diameter slightly larger than the trap mouth was suspended over each pitfall trap to avoid flooding during the rainy season and/or obstruction by falling leaves. Sampling was undertaken once a month for a year, from August 2008 to August 2009 (exceptional rainfall prevented the sampling in May 2009), giving a total of 240 samples. The pitfall traps were partially filled with a mixture of $90 \%$ ethanol $(70 \%)$ and monoethylene glycol $(30 \%)$ and operated for seven days. Drops of detergent were added in order to break surface tension.

Material analysis: Samples were sorted to separate ants from non-ants, and ants were then divided into morphospecies. Examples of each morphospecies were mounted and identified to the genus level using keys provided by Bolton (1994) and Hölldober \& Wilson (1990). Mounted specimens of each morphospecies were sent to the Museu de Zoologia of the Universidade de São Paulo (MZSP) for confirmation of the genus identification and, when possible, for identification to the species level. Some species identifications were also verified and/or confirmed by J.C.H. Delabie.

Voucher specimens are deposited at the Myrmecological Collection of the Laboratório de Entomologia, Universidade Estadual do Ceará, in Fortaleza, CE, Brazil, at the Myrmecological Collection of the Museu de Zoologia of the Universidade de São Paulo (MZSP) in São Paulo, SP, Brazil, and at the Mirmecological Collection of the Centro de Pesquisas do Cacau (CEPLAC) in Itabuna, BA, Brazil.

Precipitation data: The rainfall data were obtained from the average daily rainfall recorded at five meteorological stations maintained by FUNCEME (Ceará Foundation for Meteorology and Water Management) in the municipality of Pentecoste. The rainfall data considered for each monthly sampling referred to the rainfall observed in the three weeks preceding traps collection, plus the week the pitfall traps were operating.

For each monthly transect survey, a data matrix was constructed, in which the abundance of each ant species in each pitfall trap was 
recorded. The matrices were used to analyze the ant assemblage structure month by month and for the whole sampling period. They also allowed the calculation of species abundance (number of individuals of each species captured in the pitfall traps), species occurrence (number of pitfalls traps in which each species occurred) and mean number of individuals of each species per "positive" pitfall trap (i.e. only the pitfall traps where a species occurred were considered to calculate the mean). Chi-square test with Yates correction for continuity and Mann-Whitney $U$ test were used to compare species occurrence and species mean number of individuals per pitfall trap, in the dry and the rainy season, respectively. Only species which total abundance (summed abundance of dry and rainy seasons) was equal to, or above, 50 were considered for comparison. A Pearson product moment correlation analysis was used to investigate the existence of a correlation between ant abundance $\left(\log _{10}\right.$ transformed data) (total number of individuals found in all pitfall traps each month) and rainfall, between species occurrences (total number of species occurrences each month) and rainfall, and between the mean number of species found each month per pitfall trap and rainfall.

In order to assess the completeness of the transect survey, a species accumulation curve was plotted using the means of 1000 randomizations of sample accumulation order. Chao2, an incidence based estimator commonly used in ant studies (Longino et al. 2002), which has performed well at low sample size and which is recommended for pitfall traps (Brose 2002), was used to estimate species richness. To avoid flawed analysis due to pseudoreplication (the same transect and the same pitfall traps were used each month), only the total number of species captured in each pitfall trap for the whole sampling period was considered, giving a total of 20 samples (i.e. each sampling point with its pitfall trap working once a month during one year was considered as one sample to plot the observed and the estimated accumulation curve). The observed and the estimated accumulation curves were calculated using the software R version 2.11.1 (R Development Core Team 2010) with the add-on library vegan version 1.17-4.

\section{RESULTS}

Rainfall data: Qualitatively, the rainfall trend during the sampling period corresponded to the usual pattern observed in the State of Ceará: a dry season with almost no rain (July 2008-December 2008), a pre-rainy season in January 2009, a rainy season (February 2009-May 2009) with highest rainfall observed in March, April and May, and a post-rainy season (June 2009-August 2009). However, quantitatively, the rainy period of the year 2009 was atypical, with average precipitation about $60 \%$ more than in the past 30 years (FUNCEME 2009).

Ant fauna: In total, 19088 individuals from 41 species or morphospecies, 19 genera and six subfamilies were collected by 20 pitfall traps that operated once a month during one year (Table 1). Two of the morphospecies were represented by only one or two incomplete individuals, so it was impossible to identify them at genus and even subfamily level (Table 1). 40 and 29 species (or morphospecies) were collected in the dry and the rainy season, respectively, and species richness in monthly collections ranged from 13 to 28 species (Table 1). Myrmicinae was the most speciose subfamily (21 species), followed by Formicinae (10 species), Ponerinae (four species), Ectatomminae (two species), Ecitoninae and Pseudomyrmecinae (one species each) (Table 1). The two most species-rich genera were Pheidole (10 species) and Camponotus (eight species), with the other ones being represented by only one to three species/morphospecies (Table 1). Platythyrea sp. n. (Ponerinae) is a new and not yet described species that has been collected some years ago in the Brazilian States of Maranhão, Tocantins and Bahia (R.S.M. Feitosa, pers. comm.). The capture of that species in the present study represents the first record for the Ceará State. The presence of Thaumatomyrmex 
TABLE 1

List of sampled species in the period 08/2008-08/2009

\begin{tabular}{|c|c|c|c|c|c|c|c|c|c|c|c|c|c|c|c|}
\hline \multirow{2}{*}{ Subfamily } & \multirow{2}{*}{ Species } & \multicolumn{5}{|c|}{$2008^{1}$} & \multicolumn{8}{|c|}{$2009^{1}$} & \multirow{2}{*}{$\mathrm{O}^{4}$} \\
\hline & & VIII & IX & $\mathrm{X}$ & XI & XII & I & II & III & IV & V & VI & VII & VII & \\
\hline \multirow[t]{2}{*}{ Ectatomminae } & Ectatomma suzanae & $1^{2}$ & 1 & 2 & 4 & 4 & 5 & 3 & 2 & 2 & $* 3$ & 2 & 1 & 2 & 100 \\
\hline & Gnamptogenys striatula & 10 & 7 & 8 & 6 & 8 & 4 & 5 & 5 & 5 & $*$ & 9 & 10 & 12 & 100 \\
\hline Ecitoninae & Neivamyrmex diana & & 1 & & & & 1 & & & & $*$ & & & & 17 \\
\hline \multirow[t]{10}{*}{ Formicinae } & Brachymyrmex sp. 1 & & & 1 & & & & & & & $*$ & & 1 & & 17 \\
\hline & Brachymyrmex sp. 2 & 5 & 5 & 5 & 3 & 3 & 3 & 1 & & & $*$ & & 2 & 3 & 75 \\
\hline & Camponotus arboreus & & 2 & & & & 1 & & & & $*$ & & & 3 & 25 \\
\hline & Camponotus atriceps & 2 & 5 & 4 & 6 & 1 & & & 1 & & $*$ & 1 & & 1 & 67 \\
\hline & Camponotus crassus & 18 & 20 & 19 & 19 & 15 & 17 & 9 & 6 & 9 & $*$ & 5 & 9 & 17 & 100 \\
\hline & Camponotus fastigatus & 2 & 5 & 3 & 2 & 2 & 7 & 4 & 1 & & $*$ & 1 & 1 & 4 & 92 \\
\hline & Camponotus substitutus & 10 & 16 & 10 & 14 & 14 & 13 & 2 & 7 & 9 & $*$ & 15 & 20 & 18 & 100 \\
\hline & Camponotus vittatus & 7 & 9 & 4 & 6 & 4 & 1 & & & & $*$ & 1 & 3 & 4 & 75 \\
\hline & Camponotus sp. 1 & 3 & & 2 & & & & 2 & 2 & & $*$ & 1 & 2 & 6 & 58 \\
\hline & Camponotus sp. 2 & & & & & & 1 & & & & $*$ & & & & 8 \\
\hline \multirow[t]{21}{*}{ Myrmicinae } & Cephalotes pellans & & 1 & & & & & & & & $*$ & & & & 8 \\
\hline & Cephalotes pusillus & & 1 & 1 & & 1 & 1 & & & 1 & $*$ & & 1 & 3 & 58 \\
\hline & Crematogaster distans & & & & & 1 & 1 & & & & $*$ & & & & 8 \\
\hline & Crematogaster victima & 4 & 15 & 14 & 4 & 3 & 4 & 3 & & & $*$ & 1 & 1 & 2 & 83 \\
\hline & Cyphomyrmex rimosus & 19 & 20 & 19 & 19 & 17 & 13 & 6 & 9 & & $*$ & 15 & 16 & 17 & 92 \\
\hline & Nesomyrmex sp. nr. mirassolis & 1 & & & & 1 & & & & & $*$ & & & & 17 \\
\hline & Pheidole diligens & 20 & 20 & 20 & 20 & 19 & 19 & 18 & 15 & 11 & $*$ & 12 & 15 & 13 & 100 \\
\hline & Pheidole sp. 1 (gp.fallax) & 7 & 9 & 9 & 8 & 5 & 6 & 4 & 3 & 2 & $*$ & 2 & 2 & 4 & 100 \\
\hline & Pheidole sp. 2 (gp. diligens) & 7 & 9 & 7 & 8 & 8 & 7 & 6 & 3 & & $*$ & 1 & 1 & 2 & 92 \\
\hline & Pheidole sp. 3 (gp. fallax) & 1 & 2 & & & & & & & & $*$ & & & & 17 \\
\hline & Pheidole sp. 4 & 2 & & & & & 1 & 15 & 13 & 14 & $*$ & 15 & 13 & 7 & 67 \\
\hline & Pheidole sp. 5 (gp. diligens) & 1 & 2 & 2 & 2 & & 1 & & 2 & & $*$ & & & 2 & 58 \\
\hline & Pheidole sp. 6 (gp.flavens) & 4 & 4 & 1 & 1 & & 1 & 5 & 4 & 6 & $*$ & 8 & 13 & 15 & 92 \\
\hline & Pheidole sp. 7 (gp.fallax) & 1 & 2 & 1 & & & & & & & $*$ & 1 & & 1 & 42 \\
\hline & Pheidole sp. 8 (gp. diligens) & & 2 & 2 & & & & & & & $*$ & & & 1 & 25 \\
\hline & Pheidole sp. 9 (gp. diligens) & & & 1 & & & & & & & $*$ & & & & 8 \\
\hline & Rogeria blanda & 2 & & & & 1 & & 1 & & & $*$ & & 1 & 1 & 42 \\
\hline & Solenopsis globularia & 19 & 20 & 20 & 19 & 20 & 15 & 16 & 13 & 12 & $*$ & 14 & 16 & 17 & 100 \\
\hline & Solenopsis sp. nr. albidula & 3 & 6 & 4 & 1 & 2 & 1 & 6 & 4 & 3 & $*$ & 3 & 5 & 4 & 100 \\
\hline & Strumigenys elongata & & & & & & & 2 & 3 & 2 & $*$ & 3 & 3 & 6 & 50 \\
\hline & Wasmannia auropunctata & 1 & & 1 & & & & & & & $*$ & & & & 17 \\
\hline \multirow[t]{4}{*}{ Ponerinae } & Dinoponera quadriceps & 10 & 1 & 5 & 1 & & 5 & & & 1 & $*$ & & 1 & 2 & 67 \\
\hline & Odontomachus bauri & 2 & 3 & 2 & 2 & & & & 1 & & $*$ & 1 & 3 & 2 & 67 \\
\hline & Platythyrea sp.n. & 3 & 11 & 10 & 13 & 5 & 10 & 1 & 1 & & $*$ & 2 & 1 & 3 & 92 \\
\hline & Thaumatomyrmex mutilatus & & & & & 1 & & & & & $*$ & & & & 8 \\
\hline Pseudomyrmecinae & Pseudomyrmex acanthobius & & & & 1 & & & & & & $*$ & & & & 8 \\
\hline \multirow[t]{2}{*}{ Unidentified } & sp. 1 & & & & & 2 & & & & & $*$ & & & & 8 \\
\hline & sp. 2 & & & & & & 1 & & & & $*$ & & & & 8 \\
\hline Total no. of species & & 27 & 27 & 27 & 21 & 22 & 25 & 19 & 19 & 13 & $*$ & 21 & 24 & 28 & \\
\hline
\end{tabular}

1. dry season: VIII/2008-I/2009; rainy season: II/2009-VIII/2009.

2. number of individuals captured in the 20 pitfall traps used monthly

3. no sampling.

4. occurrence $(\%)$ in the 12 monthly samplings. 
mutilatus (Ponerinae), a Polyxenidae millipede specialist predator whose capture (one individual in the present study) is exceptionally rare with conventional/usual sampling techniques (Brandão et al. 1991, Delabie et al. 2000a), is also worth nothing. Its capture in the present study represents the second record in the Ceará state, the first one being the capture of one individual in a Caatinga area of the Reserva Natural Serra das Almas, in Crateús (Central West region of the Ceará State) $\left(05^{\circ} 10^{\prime} \mathrm{S}-40^{\circ} 40^{\prime} \mathrm{W}\right)$ (Quinet \& Tavares 2005).

The species accumulation curves (observed and estimated) show that the ground foraging ant species assemblage was relatively well sampled, and that $92.1 \%$ (95\% CI: 69.6 to $98.3 \%$ ) of the local estimated species richness (Chao2) (44.5 species; 95\% CI: 41.7 to 58.9) was collected (Fig. 1). The same conclusion can be drawn from the observed and estimated (Chao2) species richness obtained in most of the monthly samplings (Table 2).

Species occurrence and ant abundance: 13 species (mostly from Camponotus, Pheidole and Solenopsis genera) were very frequent, being collected in more than $90 \%$ of the monthly samplings (Table 1 ). Ten species were frequent (collected in more than 50\% and up to $90 \%$ of the monthly samplings), while five species had an intermediate frequency, being found in 25 to $50 \%$ of the monthly samplings; and 13 species were relatively infrequent, being collected in less than $25 \%$ of the monthly samplings (Table 1).

TABLE 2

Observed (Sobs) and estimated (Chao2) ant species richness for each sampling period

\begin{tabular}{|c|c|c|c|c|c|}
\hline Year & Month & Sobs & Chao2 & L CI & U CI \\
\hline \multirow{5}{*}{$\stackrel{\infty}{\stackrel{\overbrace{}}{\circ}}$} & August & 27 & 30.6 & 27.65 & 46.94 \\
\hline & September & 27 & 29.5 & 27.4 & 42.65 \\
\hline & October & 27 & 30.6 & 27.65 & 46.94 \\
\hline & November & 21 & 23.67 & 21.38 & 39.86 \\
\hline & December & 22 & 28 & 23.07 & 55.62 \\
\hline \multirow{8}{*}{ ஓి } & January & 25 & 77.25 & 41.67 & 188.73 \\
\hline & February & 19 & 20.5 & 19.17 & 31.89 \\
\hline & March & 19 & 21.67 & 19.38 & 37.86 \\
\hline & April & 13 & 13.67 & 13.06 & 20.8 \\
\hline & May & $*$ & $*$ & $*$ & * \\
\hline & June & 21 & 31.67 & 23.18 & 73.18 \\
\hline & July & 24 & 37.5 & 26.9 & 86.88 \\
\hline & August & 28 & 29.33 & 28.18 & 38.13 \\
\hline
\end{tabular}

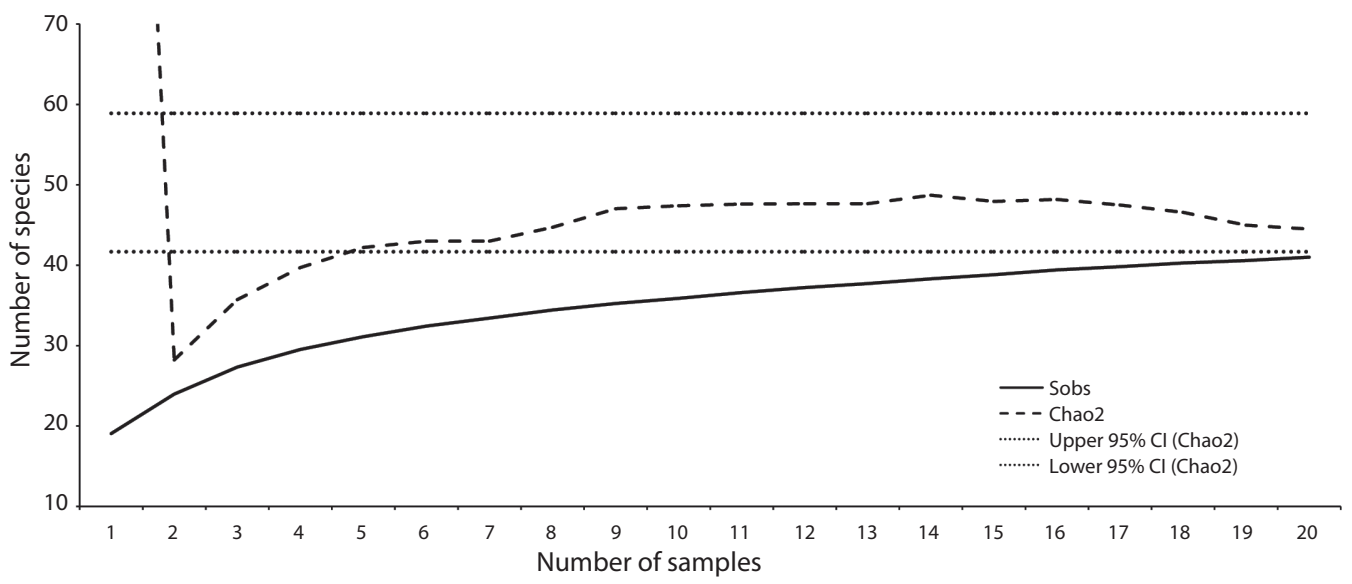

Fig. 1. Species accumulation curve for the whole sampling period. The total number of species captured in each of the 20 pitfall traps for the whole sampling period was used to plot the curve. Sobs: number of observed species. Chao2: estimated number of species with the Chao2 richness estimator. Upper 95\% CI (Chao2): Chao2 95\% confidence interval upper bound. Lower 95\% CI (Chao2): Chao2 95\% confidence interval lower bound. 


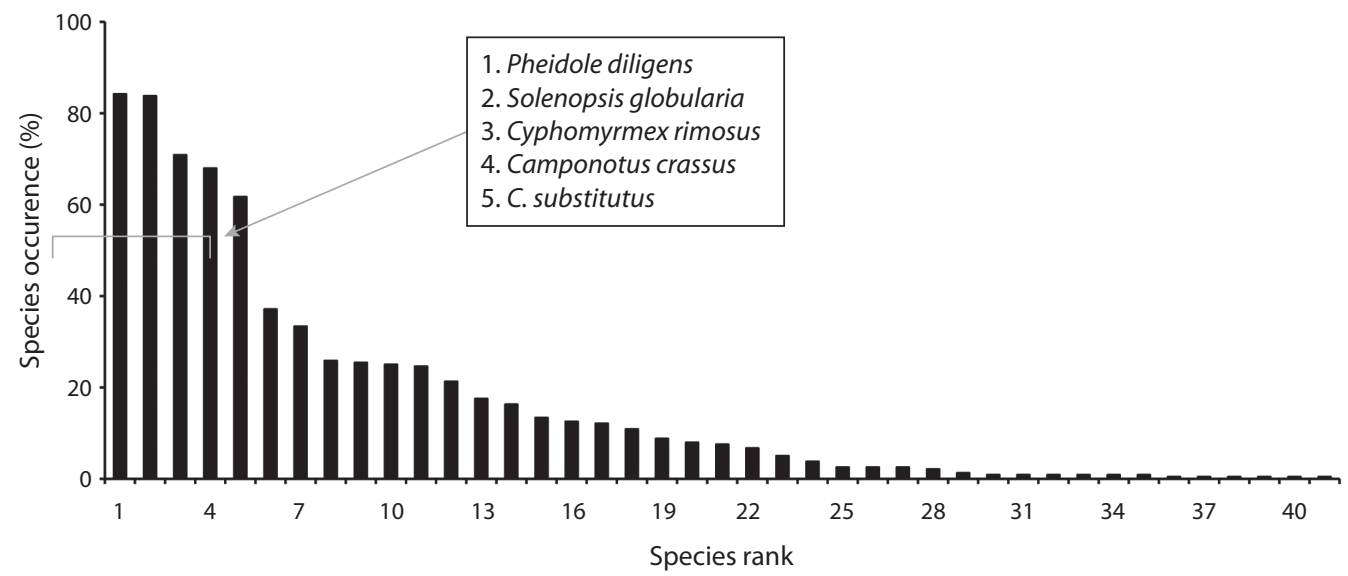

Fig. 2. Occurrence $(\%)$ of each of the 41 species/morphospecies captured in the sampling period (08/2008 - 08/2009). Species occurrence is here defined as the proportion of samples (from a total of 240) in which each species was found.

Five species (Camponotus crassus, C. substitutus, Cyphomyrmex rimosus, Pheidole diligens and Solenopsis globularia) had a high occurrence, being found in more than $50 \%$ of the 240 samples (Fig. 2). 14 species had an intermediate occurrence, being found in 10.8 to $37 \%$ of the samples, while 22 species were considered "rare", occurring in less than $10 \%$ of the samples (Fig. 2). A high abundance (more than 500 individuals for the whole sampling period) also characterized the five species with highest occurrence (Fig. 3). Those species were responsible for most of the total abundance observed each month (Fig. 4) and accounted for $84.5 \%$ of all ants found in pitfall traps from August 2008 to August 2009, with P. diligens alone representing $44.2 \%$ of all captured ants.

Ant abundance, species occurrences, mean number of species per pitfall trap, and rainfall: Total ant abundance (added number of individuals of all species) exhibited a drastic decrease during the rainy season (4 083 individuals captured in the rainy season, against 15 005 in the dry season), especially in months with high rainfall (Fig. 4), and a negative linear correlation was found between rainfall and total ant abundance $\left(\log _{10}\right.$ transformed data) (Pearson product moment correlation analysis;
$\mathrm{N}=12$ samplings, $\mathrm{r}=-0.83, \mathrm{p}<0.001)$ (Fig. 5A). A similar negative linear correlation was found for species occurrences against rainfall $(\mathrm{N}=12$ samplings, $\mathrm{r}=-0.85, \mathrm{p}<0.001)$, and for mean number of species per pitfall trap against rainfall $(\mathrm{N}=12$ samplings, $\mathrm{r}=-0.84, \mathrm{p}<0.001)$ (Figs. $5 \mathrm{~B}$ and $\mathrm{C})$.

However, a more refined analysis of ant species whose abundance (added dry and rainy seasons abundance) was equal to or above 50, showed that effect of rainfall on pitfall trap performance was not equal for all ant species (Table 3). A first group (Brachymyrmex sp. 2,

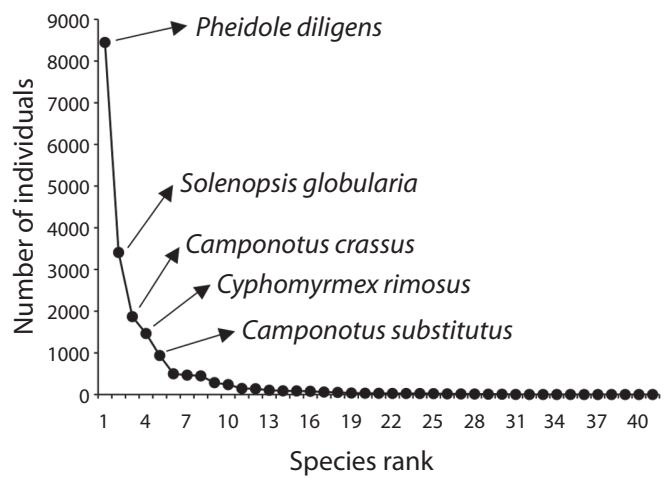

Fig. 3. Total abundance (total number of individuals for the whole sampling period) for each captured species. 


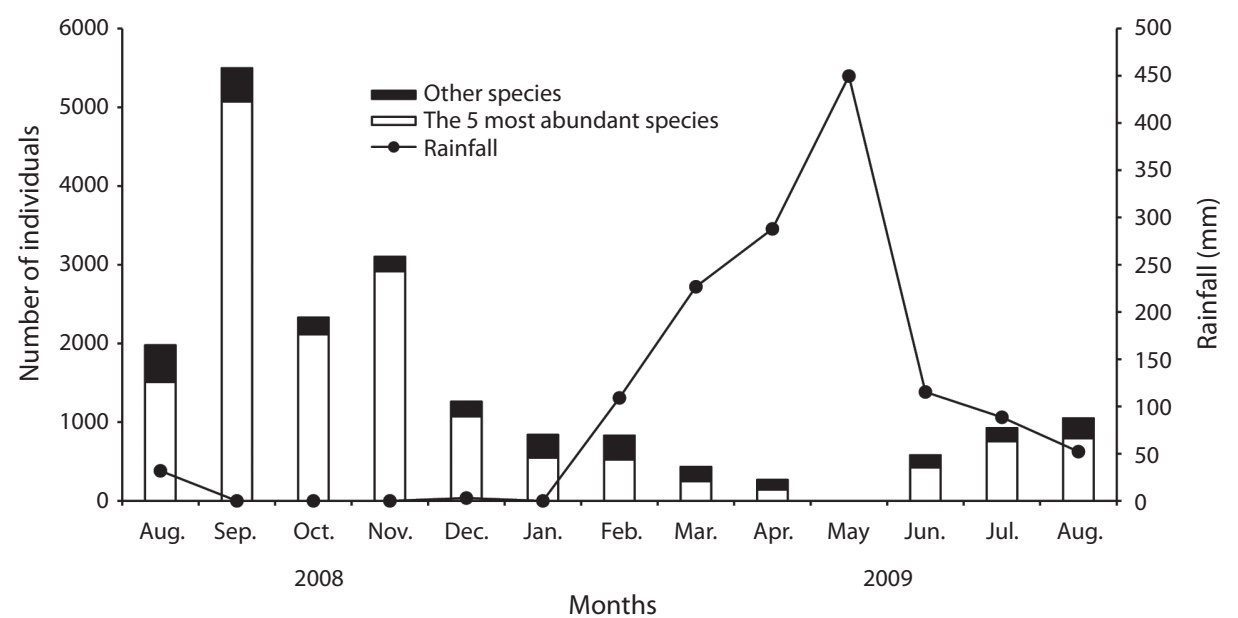

Fig. 4. Total number of ants found each month in the 20 pitfall traps, and rainfall. The five most abundant species are: Camponotus crassus, C. substitutus, Cyphomyrmex rimosus, Pheidole diligens and Solenopsis globularia.

TABLE 3

List of species whose total abundance for the whole sampling period was higher than 50 , with their respective abundance

$(\mathrm{Ab})$, occurrence $(\%)(\mathrm{O})$ and mean abundance per pitfall trap $(\mathrm{Ab} / \mathrm{PF})$, in the dry $(\mathrm{D})$ and the rainy $(\mathrm{R})$ season

\begin{tabular}{|c|c|c|c|c|c|c|}
\hline \multirow{2}{*}{ Species } & \multicolumn{2}{|c|}{$\mathrm{Ab}$} & \multicolumn{2}{|c|}{$\mathrm{O}$} & \multicolumn{2}{|c|}{$\mathrm{Ab} / \mathrm{PF}($ mean $\pm \mathrm{SD})$} \\
\hline & $\mathrm{D}$ & $\mathrm{R}$ & $\mathrm{D}$ & $\mathrm{R}$ & $\mathrm{D}$ & $\mathrm{R}$ \\
\hline Pheidole diligens & 7295 & 1152 & $98.3^{\mathrm{a}}$ & $70^{\mathrm{b}}$ & $61.8 \pm 132.2^{\mathrm{a}}$ & $13.7 \pm 26.4^{b}$ \\
\hline Solenopsis globularia & 2594 & 811 & $94.1^{\mathrm{a}}$ & $73.3^{\mathrm{b}}$ & $22.9 \pm 33^{\mathrm{a}}$ & $9.2 \pm 10.6^{\mathrm{b}}$ \\
\hline Camponotus crassus & 1746 & 123 & $90^{\mathrm{a}}$ & $45.8^{\mathrm{b}}$ & $16.2 \pm 15.2^{\mathrm{a}}$ & $2.2 \pm 2.5^{\mathrm{b}}$ \\
\hline Cyphomyrmex rimosus & 1134 & 330 & $89.2^{\mathrm{a}}$ & $52.5^{\mathrm{b}}$ & $10.6 \pm 14.9^{\mathrm{a}}$ & $5.2 \pm 10.5^{\mathrm{b}}$ \\
\hline Pheidole sp. 2 (gp. diligens) & 417 & 31 & $38.3^{\mathrm{a}}$ & $10.8^{\mathrm{b}}$ & $9.1 \pm 19.6^{\mathrm{a}}$ & $2.4 \pm 4.2^{\mathrm{b}}$ \\
\hline Pheidole sp. 1 (gp.fallax) & 250 & 35 & $36.7^{\mathrm{a}}$ & $14.2^{\mathrm{b}}$ & $5.7 \pm 6.4^{\mathrm{a}}$ & $2.1 \pm 1.8^{\mathrm{b}}$ \\
\hline Crematogaster victima & 130 & 9 & $36.7^{\mathrm{a}}$ & $5.8^{\mathrm{b}}$ & $2.9 \pm 2.4^{\mathrm{a}}$ & $1.3 \pm 0.8^{\mathrm{b}}$ \\
\hline Platythyrea sp. n. & 81 & 8 & $43.3^{\mathrm{a}}$ & $6.7^{\mathrm{b}}$ & $1.6 \pm 0.85^{*}$ & $1 \pm 0^{*}$ \\
\hline Brachymyrmex sp. 2 & 63 & 15 & $20^{\mathrm{a}}$ & $5^{\mathrm{b}}$ & $2.6 \pm 2.7^{\mathrm{a}}$ & $2.5 \pm 2.1^{\mathrm{a}}$ \\
\hline Camponotus vittatus & 52 & 9 & $25.8^{\mathrm{a}}$ & $6.7^{\mathrm{b}}$ & $1.7 \pm 1.2^{\mathrm{a}}$ & $1.1 \pm 0.3^{\mathrm{a}}$ \\
\hline Camponotus substitutus & 462 & 475 & $64.2^{\mathrm{a}}$ & $59.2^{\mathrm{a}}$ & $6 \pm 22.6^{a}$ & $6.7 \pm 20.5^{\mathrm{a}}$ \\
\hline Gnamptogenys striatula & 280 & 218 & $35.8^{\mathrm{a}}$ & $38.3^{\mathrm{a}}$ & $6.5 \pm 9.6^{\mathrm{a}}$ & $4.7 \pm 4.7^{\mathrm{a}}$ \\
\hline Ectatomma suzanae & 117 & 121 & $14.2^{\mathrm{a}}$ & $10^{\mathrm{a}}$ & $6.9 \pm 7^{\mathrm{a}}$ & $10.1 \pm 10.4^{\mathrm{a}}$ \\
\hline Solenopsis sp. nr. albidula & 39 & 48 & $14.2^{\mathrm{a}}$ & $20.8^{\mathrm{a}}$ & $2.3 \pm 2.4^{\mathrm{a}}$ & $1.9 \pm 1.4^{\mathrm{a}}$ \\
\hline Camponotus fastigatus & 35 & 16 & $17.5^{\mathrm{a}}$ & $9.2^{\mathrm{a}}$ & $1.7 \pm 1.1^{\mathrm{a}}$ & $1.5 \pm 0.9^{\mathrm{a}}$ \\
\hline Pheidole sp. 4 & 12 & 454 & $2.5^{\mathrm{a}}$ & $64.2^{\mathrm{b}}$ & $4 \pm 3.6^{\mathrm{a}}$ & $5.9 \pm 8.7^{\mathrm{a}}$ \\
\hline Pheidole sp. 6 (gp.flavens) & 22 & 123 & $9.2^{\mathrm{a}}$ & $42.5^{\mathrm{b}}$ & $2 \pm 3^{\mathrm{a}}$ & $2.4 \pm 2.5^{\mathrm{a}}$ \\
\hline
\end{tabular}

The occurrence and the mean abundance per pitfall observed, for each species, in the dry and the rainy season were compared using a $\mathrm{X}^{2}$ test $(\mathrm{df}=1)$ and a Mann-Whitney $\mathrm{U}$ test respectively. Percentages or means sharing the same letter are not significantly different (level of significance $\alpha=0.05$ ). 

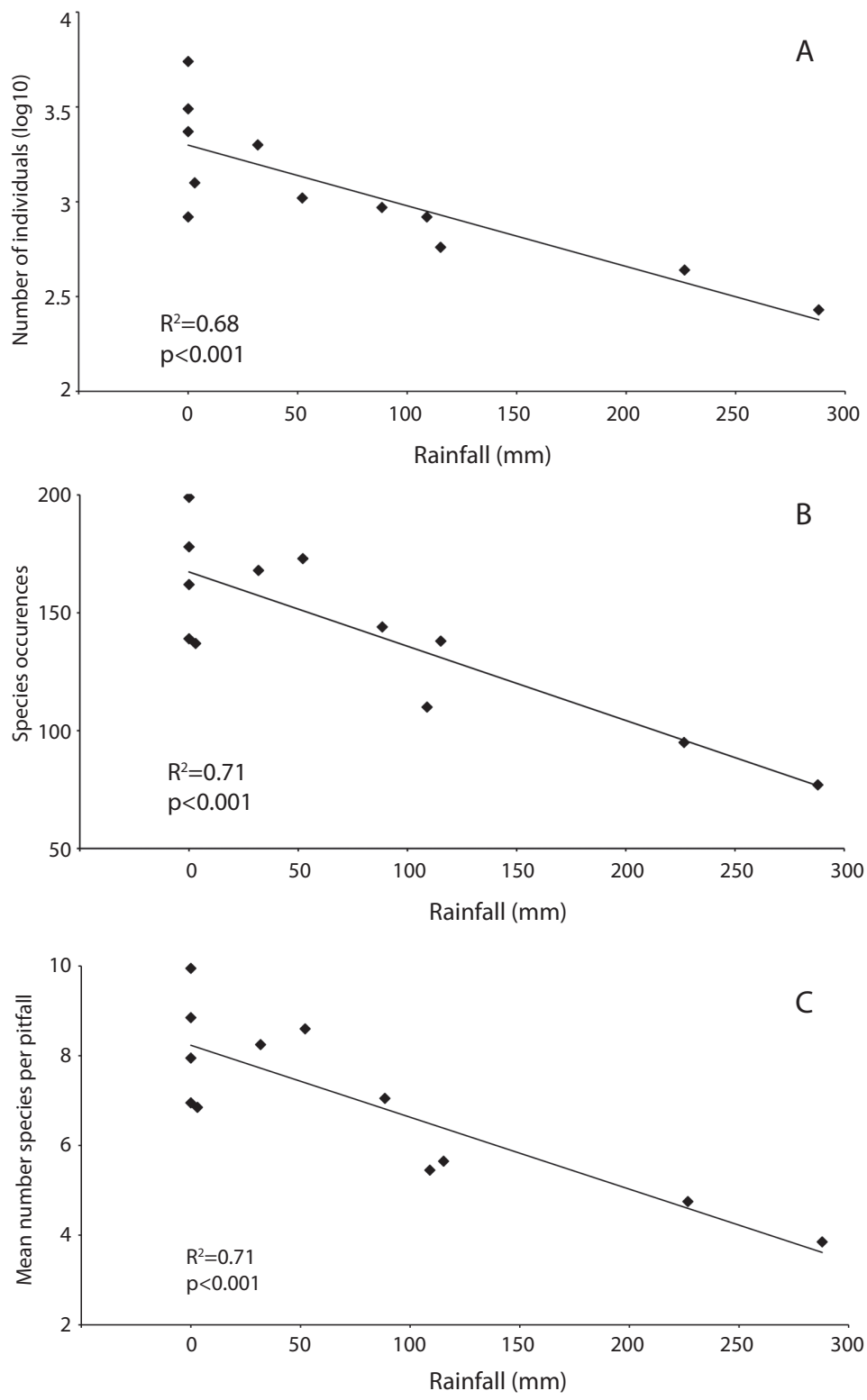

Fig. 5. Relationship between rainfall and (A) the total number of individuals captured each month, (B) the total number of species occurrences found each month, and (C) the mean number of species found in the pitfall traps each month.

Camponotus crassus, $C$. vittatus, Crematogaster victima, Cyphomyrmex rimosus, Pheidole diligens, Pheidole sp. 1, Pheidole sp. 2, Platythyrea sp. n., Solenopsis globularia) showed a strong decrease in abundance, occurrence and mean number of individuals per pitfall trap in the rainy season (the difference in the mean number of individuals per pitfall trap between the dry and the rainy season was not significant for Brachymyrmex sp. 2 and C. vittatus) (Table 3). A second group (Camponotus fastigatus, C. substitutus, Ectatomma suzannae, 
Gnamptogenys striatula, Solenopsis sp. nr. albidula) showed equal abundance, occurrence and mean number of individuals per pitfall trap in both seasons (Table 3). A third group (Pheidole sp. 4, Pheidole sp. 6) showed a much higher abundance and occurrence during the rainy season (Table 3). However, there was no difference in the number of individuals per pitfall trap between the two seasons (Table 3). It is also worth nothing that Strumigenys elongata was captured only in the rainy season (25 individuals captured in a total of 19 pitfall traps), being found in all the monthly samplings realized during the rainy season (Table 1).

\section{DISCUSSION}

Taking into account the potential biases of pitfall trapping (Bestelmeyer et al. 2000, Gotteli et al. 2011), the limited sampling effort and the very localized sampling area in the present study (one transect sampled each month during one year), the species richness found (a total of 41 species/morphospecies, with monthly species/morphospecies richness ranging from 13 to 28 ) can be considered as high as, and comparable with species richness found in studies performed with more and less similar sampling effort in the few studies undertaken in the Caatinga biome (Leal 2003, Quinet \& Tavares 2005), and also in other savanna-like habitat, like the South African savanna (Lindsey \& Skinner 2001, Parr \& Chown 2001), the Paraguayan Chaco (Delsinne et al. 2008, 2010) or the Brazilian Cerrado (Lopes \& Vasconcelos 2008).

In other tropical biomes, such as Atlantic rainforest or Amazon rainforest, many species are litter specialist predators (Delabie et al. 2000b, Vasconcelos \& Vilhena 2006, Wilkie et al. 2010), a situation that contrasts with the present study where most of the 41 captured ant species/morphospecies are generalized foragers, like those of the Camponotus, Crematogaster, Pheidole or Solenopsis (Brown 2000). Only the four poneroid species (Dinoponera quadriceps, Odontomachus bauri, Platythyrea sp. n., Thaumatomyrmex mutilatus), the two ectatommine species (Ectatomma suzanae, Gnamptogenys striatula), the unique ecitonine species (Neivamyrmex diana) and Strumigenys elongata (Myrmicinae) are solely or partly predators (Brown 2000, Arias-Penna 2008, Fernández 2008, Powell \& Baker 2008). Among them, only two species (S. elongata, T. mutilatus) are litter specialist predators (perhaps three, considering Platythyrea sp. n.) (Brandão et al. 1991, Brown 1962, 2000, Delabie et al. 2000a). This low number of predator species, especially litter specialist ones, could in part be the consequence of inadequate sampling techniques, since pitfall traps mostly collect surface-active ants (Bestelmeyer et al. 2000). However, the lack (permanent or seasonal), the reduced availability, or the patchy distribution, of leaf-litter in the Caatinga environment could also be a strong limiting factor for litter dwelling and/or foraging species, and for their regular prey, as also pointed out by Leal (2003). Furthermore, during the dry season, the microclimatic conditions inside the leaf litter could be very stressful, as suggested by Delsinne et $a l$. (2008) for the dry forests of the Paraguayan Chaco. The capture of $S$. elongata only during the rainy season, a leaf litter specialist predator of springtails (Collembola) (Brown 1962), could be a consequence of higher foraging activity during the rainy season, in response to higher activity of their collembolan prey.

The strong negative correlation found between rainfall and pitfall trap efficiency, in terms of total ant abundance, species occurrence and mean number of species per pitfall trap, was also observed by Delsinne et al. (2008) in experiments testing the extent which the two main methods (pitfall traps and Winkler extractions) used in the A.L.L. (Ants of the Leaf Litter) protocol (Agosti \& Alonso 2000) were affected by the rainfall regime in the Paraguayan Chaco. Delsinne et al. (2008) argued that the better performance of pitfall traps during low rainfall or drought conditions could be related to the attractiveness of the water they contained. Such an explanation cannot account for the present study, since the preservative used was a mixture of ethanol/monoethylene 
glycol that is believed neither to attract nor to repel ants (Bestelmeyer et al. 2000). Among the alternative factors potentially responsible for lower pitfall trap performance during the rainy season, at least three, not mutually exclusive ones, should be considered. First, strong rainfall could negatively affect ant populations, or even be a mechanical impediment for the foraging activities of foragers, at least for some ground-dwelling species. Secondly, rainfall could negatively affect the trappability (probability of capture of an individual in a population by pitfall traps, as defined by Melbourne (1999)) of some ant species, since activity levels and movement rates of cursorily arthropods like ant foragers could be affected by changes in temperature and/or humidity levels associated with the rainfall (Southwood 1978). Finally, rainfall and the consequent higher food supply for ant colonies (i.e. higher nectar, honeydew and prey availability) could result in reduced foraging time and/or journeys by foragers that could restrict their activities to areas near the colonies, therefore reducing their trappability. However, whatever the validity of the above explanations, they do not apply to all species, since the trappability of some species (C.fastigatus, C. substitutus, E. suzannae, $G$. striatula, $S$. sp. nr. albidula) is not affected by rainfall, and is even much higher during the rainy season for two of them (Pheidole sp. 4, Pheidole sp. 6).

In conclusion, pitfall trapping seems to be a satisfactory method if the aim is to obtain data about species composition of ground-foraging ants assemblages of the Caatinga biome and it should be preferentially performed in the dry season if time is a limiting factor. However, abundance and/or occurrence data obtained in different seasons should be considered with caution since the trappability of many species is reduced with rainfall, while it is unchanged or even higher for others. Furthermore, the dry season appears to be the best one to obtain reliable abundance and/or occurrence data.

\section{ACKNOWLEDGMENTS}

We thank Rodrigo Feitosa (Museu de Zoologia of the Universidade de São Paulo MZSP) and Jacques Delabie (Laboratório de Mirmecologia - CEPLAC - Itabuna - Bahia) for their assistance with the identification of the ants. Nunes F.A. was supported by a Master's fellowship from the CAPES (Coordenação de Aperfeiçoamento de Pessoal de Nível Superior). We also thank the three anonymous reviewers whose valuable comments and suggestions greatly improved this work, and Mario Xavier Ruiz-González who translated the abstract into Spanish.

\section{RESUMEN}

La Caatinga semiárida es el cuarto bioma más grande de Brasil. Pese a ello, es también el bioma brasileño cuya biota continúa siendo la más pobremente estudiada, especialmente en lo que se refiere a grupos de invertebrados. En este estudio se examinó durante un año el grupo de hormigas que forrajean en el suelo de un área de Caatinga y se evaluó el efecto de la lluvia sobre las trampas de caída. El estudio se llevó a cabo en un área del municipio de Pentecoste (348' S - 39²0' W), estado de Ceará. Se estableció un transecto de $200 \mathrm{~m}$ con 20 puntos de muestreo equidistantes. El muestreo del transecto se realizó mensualmente durante 12 meses, entre Agosto 2008-Agosto 2009. En cada punto de muestreo se colocó al principio de cada mes una trampa de caída parcialmente llena con una mezcla de etanol y monoetilenglicol y se mantuvo en el campo durante siete días. Se recogieron 39 especies pertenecientes a seis subfamilias y 19 géneros, además de dos especies sin identificar, siendo Pheidole (10 spp) y Camponotus (8 spp) los taxones con más especies. Veintitrés especies fueron frecuentes, se registraron en más del 50\% de los 12 transectos muestreados. Cinco especies tuvieron una frecuencia intermedia (25 a 50\%), mientras 13 fueron relativamente infrecuentes (menos del 25\%). La mayoría de las especies (22) mostraron una presencia baja, encontrándose en menos del 10\% de las 240 muestras (20 muestras cada mes durante 12 meses). Sólo cinco especies fueron recogidas en más del 50\% de las muestras, fueron además responsables de casi toda la abundancia total (número de individuos capturados de todas las especies) mensual. Las curvas de acumulación de especies (observadas y estimadas) indicaron que se consiguió un muestreo suficiente y que se había recogido cerca del $92 \%$ de la fauna estimada de hormigas 
terrícolas forrajeras. Se recogieron 40 y 29 especies durante las estaciones seca y lluviosa, respectivamente, con una riqueza de especies mensual entre 13 y 28 . La abundancia total de especies mostró una disminución drástica durante la estación de lluvias, y se encontró una correlación linear negativa entre la pluviosidad y la abundancia total de hormigas $\left(R^{2}=0.68\right)$. Una correlación linear negativa similar se encontró entre la ocurrencia de especies y la pluviosidad $\left(\mathrm{R}^{2}=0.71\right)$, y entre el número medio de especies por trampa de caída y la pluviosidad $\left(\mathrm{R}^{2}=0.71\right)$. Sin embargo, mientras se observó que algunas especies tenían la misma abundancia, presencia, y número medio de individuos por trampa de caída en ambas estaciones, otras tenían una abundancia y presencia mucho mayor durante la estación lluviosa. Se discute el uso de trampas de caída como método para muestrear el grupo de hormigas que forrajean en el suelo del bioma de la Caatinga, así como los factores potenciales responsables del rendimiento más bajo de las trampas de caída durante la estación lluviosa.

Palabras clave: Caatinga semi-árida, Formicidae, grupo de hormigas que forrajean en el suelo, trampas de caída, lluvia.

\section{REFERENCES}

Agosti, D. \& L.E. Alonso. 2000. The ALL protocol: A standard protocol for the collection of ground-dwelling ants, p. 204-206. In D. Agosti, J.D. Majer, L.E. Alonso \& T.R. Schultz (eds.). Ants standard methods for measuring and monitoring biodiversity. Smithsonian Institution, Washington D.C., USA.

Agosti, D., J. Majer, L.E. Alonso \& T.R. Schultz. 2000. Sampling ground-dwelling ants: Case studies from the world's rain forests. Curtin University School of Environmental Biology Bulletin No. 18, Perth, Australia.

Alonso, L.E. \& D. Agosti. 2000. Biodiversity studies, monitoring, and ants: An overview, p. 1-8. In D. Agosti, J.D. Majer, L.E. Alonso \& T.R. Schultz (eds.). Ants standard methods for measuring and monitoring biodiversity. Smithsonian Institution, Washington D.C., USA.

Andrade-Lima, D. 1981. The caatinga dominium. Rev. Bras. Bot. 4: 149-163.

Andrade-Lima, D. 1982. Present day forest refuges in North-eastern Brazil, p. 245-254. In G.T. Prance (ed.). Biological diversification in the tropics. Columbia University, New York, USA.

Arias-Penna, T.M. 2008. Subfamilia Ectatomminae, p. 53-107. In E. Jiménez, F. Fernández, T.M. Arias \& F.H. Lozano-Zambrano (eds.). Sistemática, biogeografía y conservación de las hormigas cazadoras de Colombia. Instituto de Investigación de Recursos Biológicos Alexander Von Humboldt, Bogotá, Colombia.

Bestelmeyer, B.T., D. Agosti, L.E. Alonso, C.R.F. Brandão, W.L. Brown Jr., J.H.C. Delabie \& R. Silvestre. 2000. Field techniques for the study of ground-dwelling ants: An overview, description, and evaluation, p. 122-144. In D. Agosti, J.D. Majer, L.E. Alonso \& T.R. Schultz (eds.). Ants standard methods for measuring and monitoring biodiversity. Smithsonian Institution, Washington D.C., USA.

Bolton, B. 1994. Identification guide to the ants genera of the world. Harvard University, Cambridge, Massachussets, USA.

Brandão, C.R.F., J. Diniz \& E. Tomotake. 1991. Thaumatomyrmex strips millipedes for prey: a novel predatory behaviour in ants, and the first case of sympatry in the genus (Hymenoptera: Formicidae). Insectes Soc. 38: 335-344.

Brose, U. 2002. Estimating species richness of pitfall catches by non-parametric estimators. Science 107 : 101-107.

Brown, W.L. 1962. The neotropical species of the ant genus Strumigenys Fr. Smith: Synopsis and keys to the species. Psyche 69: 238-267.

Brown, W.L. 2000. Diversity of ants, p. 45-79. In D. Agosti, J.D. Majer, L.E. Alonso \& T.R. Schultz (eds.). Ants standard methods for measuring and monitoring biodiversity. Smithsonian Institution, Washington D.C., USA.

Costa, R.C., F.S. Araújo \& L.W. Lima-Verde. 2007. Flora and life-form spectrum in an area of deciduous thorn woodland (caatinga) in northeastern, Brazil. J. Arid Environ. 68: 237-247.

Delabie, J.H.C., D. Fresneau \& A. Pezon. 2000a. Notes on the ecology of Thaumatomyrmex spp. (Hymenoptera: Formicidae: Ponerinae) in southeast Bahia, Brazil. Sociobiology 36: 571-584.

Delabie, J.C.H., D. Agosti \& I.D. Nascimento. 2000b. Litter ant communities of the Brazilian Atlantic rain forest region, p. 1-18. In D. Agosti, J.D. Majer, L.E. Alonso \& T.R. Schultz (eds.). Sampling grounddwelling ants: Case studies from the world's rain forests. Curtin University School of Environmental Biology Bulletin 18, Perth, Australia.

Delabie, J.H.C., B.L. Fisher, J.D. Majer \& I.W. Wright. 2000c. Sampling effort and choice of methods, p. 145-154. In D. Agosti, J.D. Majer, L.E. Alonso \& T.R. Schultz (eds.). Ants standard methods for 
measuring and monitoring biodiversity. Smithsonian Institution, Washington D.C., USA.

Delsinne, T., M. Leponce, T. Laurence, Y. Braet \& Y. Roisin. 2008. Rainfall influences ant sampling in dry forests. Biotropica 40: 590-596.

Delsinne, T., Y. Roisin, J. Herbauts \& M. Leponce. 2010. Ant diversity along a wide rainfall gradient in the Paraguayan dry Chaco. J. Arid Environ. 74: 1149-1155.

Diniz, J.L.M., C.R.F. Brandão \& C.I. Yamamoto. 1998. Biology of Blepharidatta ants, the sister group of the Attini: a possible origin of fungus-ant symbiosis. Naturwissenschaften 85: 270-274.

Dunn, R.R., B. Guénard, M.D. Weiser \& N.J. Sanders. 2010. Geographic gradients, p. 38-58. In L. Lach, C.L. Parr \& K.L. Abbott (eds.). Ant ecology. Oxford University, New York, USA.

Fernández, F. 2008. Subfamilia Ponerinae s.str., p. 123218. In E. Jiménez, F. Fernández, T.M. Arias \& F.H. Lozano-Zambrano (eds.). Sistemática, biogeografía y conservación de las hormigas cazadoras de Colombia. Instituto de Investigación de Recursos Biológicos Alexander Von Humboldt, Bogotá, Colombia.

Fisher, B.L. 2010. Biogeography, p. 18-37. In L. Lach, C.L. Parr \& K.L. Abbott (eds.). Ant ecology. Oxford University, New York, USA.

FUNCEME. 2009. Fundação Cearense de Meteorologia, Governo do Estado do Ceará, Brazil. (Downloaded: December 2009, http://www.funceme.br).

Giulietti, A.M., A.L. du Bocage Neta, A.A.J.F. Castro, C.F.L. Gamarra-Rojas, E.V.S.B. Sampaio, J.F. Virgínio, L.P. Queiroz, M.A. Figueiredo, M.J.N. Rodal, M.R.V. Barbosa \& R.M. Harley. 2004. Diagnóstico da vegetação nativa do bioma Caatinga, p. 48-90. In J.M.C. Silva, M. Tabarelli, M. Fonseca \& L. Lins (eds.). Biodiversidade da Caatinga: Áreas e Ações Prioritárias Para a Conservação. Ministério do Meio Ambiente, Brasília, Brazil.

Gotelli, N.J., A.M. Ellison, R.R. Dunn \& N.J. Sanders. 2011. Counting ants (Hymenoptera: Formicidae): biodiversity sampling and statistical analysis for myrmecologists. Myrmecol. News 15: 13-19.

Hölldobler, B. \& E.O. Wilson. 1990. The ants. Belknap, Cambridge, Massachusetts, USA.

IBGE. 1993. Mapa de vegetação do Brasil. IBGE, Rio de Janeiro, Rio de Janeiro, Brazil.

Kaspari, M. 2000. A primer on ant ecology, p. 9-24. In D. Agosti, J.D. Majer, L.E. Alonso \& T.R. Schultz (eds.).
Ants standard methods for measuring and monitoring biodiversity. Smithsonian Institution, Washington D.C., USA.

Kaspari, M. \& J.D. Majer. 2000. Using ants to monitor environmental change, p. 89-98. In D. Agosti, J.D. Majer, L.E. Alonso \& T.R. Schultz (eds.). Ants standard methods for measuring and monitoring biodiversity. Smithsonian Institution, Washington D.C., USA.

Leal, I.R. 2003. Diversidade de formigas em diferentes unidades de paisagem da Caatinga, p. 435-462. In I.R. Leal, M. Tabarelli \& J.M.C. Silva (eds.). Ecologia e Conservação da Caatinga. Universitária da UFPE, Recife, Brazil.

Leal, I.R., J.M.C. Silva, M. Tabarelli \& T. Lacher. 2005. Changing the course of biodiversity conservation in the Caatinga of Northeastern Brazil. Conserv. Biol. 19: 701-706.

Lewinsohn, T.M. \& P.I. Prado. 2002. Biodiversidade Brasileira: síntese de estado atual do conhecimento. Contexto, São Paulo, São Paulo, Brazil.

Lindsey, P.A. \& J.D. Skinner. 2001. Ant composition and activity patterns as determined by pitfall trapping and other methods in three habitats in the semi-arid Karoo. J. Arid Environ. 48: 551-568.

Longino, J.T., J. Coddington \& R.K. Colwell. 2002. The ant fauna of a tropical rain forest: estimating species richness three different ways. Ecology 83: 689-702.

Lopes, C.T. \& H.L. Vasconcelos. 2008. Evaluation of three methods for sampling ground-dwelling ants in the Brazilian Cerrado. Neotrop. Entomol. 37: 399-405.

Martins, C.F., F.C.V. Zanella \& Y.P. Quinet. 2005. Diversidade de artrópodes em áreas prioritárias para conservação da Caatinga, p. 319-325. In F.S. Araujo, M.J.N. Rodal \& M.J.N. Barbosa (eds.). Análise das variações da biodiversidade do bioma Caatinga, MMA, Brasília, Brazil.

Melbourne, B.A. 1999. Bias in the effect of habitat structure on pitfall traps: an experimental evaluation. Aust. J. Ecol. 24: 228-239.

Ness, J., K. Mooney \& L. Lach. 2010. Ants as mutualists, p. 97-114. In L. Lach, C.L. Parr \& K.L. Abbott (eds.). Ant ecology. Oxford University, New York, USA.

Oliveira, J.A., P.R. Gonçalves \& C.R. Bonvicino. 2003. Mamíferos da Caatinga, p. 275-333. In I.R. Leal, M. Tabarelli \& J.M.C. Silva (eds.). Ecologia e Conservação da Caatinga. Universitária da UFPE, Recife, Brazil. 
Parr, C.L. \& S.L. Chown. 2001. Inventory and bioindicator sampling: testing pitfall and Winkler methods with ants in a South African savanna. J. Insect Conserv. 5: $27-36$

Passera, L. \& S. Aron. 2005. Les fourmis: comportement, organisation sociale et évolution. Les Presses scientifiques du CNRC, Ottawa, Canada.

Pennington, R.T., D.E. Prado \& C.A. Pendry. 2000. Neotropical seasonally dry forests and quaternary vegetation changes. J. Biogeogr. 27: 261-273.

Powell, S. \& B. Baker. 2008. Os grandes predadores dos neotrópicos: comportamento, dieta e impacto das formigas de correição (Ecitoninae), p. 18-37. In E.F. Vilela, I.A. Santos, J.H. Schroereder, J.E. Serrão, L.A.O. Campos \& J. Lino-Neto (eds.). Insetos Sociais: da Biologia à Aplicação. Universidade Federal de Viçosa, Viçosa, Brazil.

Prado, D.E. 2003. As Caatingas da América do Sul, p. 3-74. In I.R. Leal, M. Tabarelli \& J.M.C. Silva (eds.). Ecologia e conservação da Caatinga. Universitária da UFPE, Recife, Brazil.

Quinet, Y.P. \& A.A. Tavares. 2005. Formigas (Hymenoptera:Formicidae) da área Reserva Serra das Almas, Ceará, p. 327-348. In F.S. Araujo, M.J.N. Rodal \& M.J.N. Barbosa (eds.). Análise das Variações da Biodiversidade do Bioma Caatinga, MMA, Brasília, Brazil.

Rizzini, C.T. 1963. Nota prévia sobre a divisão fitogeográfica (florístico-sociológica) do Brasil. Rev. Bras. Geog. 25: 1-64.

Rizzini, C.T. 1997. Tratado de fitogeografia do Brasil. Âmbito Cultural, Rio de Janeiro, Rio de Janeiro, Brazil.

R Development Core Team. 2010. R: A Language and environment for statistical computing. R Foundation for Statistical Computing, Vienna, Austria. (Available online: http://www.r-project.org).

Rodrigues, M.F. 2003. Herpetofauna da Caatinga, p. 181236. In I.R. Leal, M. Tabarelli \& J.M.C. Silva (eds.). Ecologia e conservação da Caatinga. Universitária da UFPE, Recife, Brazil.
Romero, H. \& K. Jaffé. 1989. A comparison of methods for sampling ants (Hymenoptera: Formicidae) in savannas. Biotropica 21: 348-352.

Rosa, R.S., N.A. Menezes, H.A. Britski, W.J.E.M. Costa \& F. Groth. 2003. Diversidade, padrões de distribuição e conservação dos peixes da Caatinga, p. 135-180. In I.R. Leal, M. Tabarelli \& J.M.C. Silva (eds.). Ecologia e conservação da Caatinga. Universitária da UFPE, Recife, Brazil.

Schultz, T.R. \& T.P. McGlynn. 2000. The intereactions of ants with organisms, p. 35-44. In D. Agosti, J.D. Majer, L.E. Alonso \& T.R. Schultz (eds.). Ants standard methods for measuring and monitoring biodiversity. Smithsonian Institution, Washington D.C., USA.

Silva, P.R. 2007. Biologia de algumas espécies de Blepharidatta. Biológico 69: 161-164.

Silva, J.M.C., M.A. Souza, A.G.D. Bieber \& C.J. Carlos. 2003. Aves da Caatinga: status, uso do habitat e sensitividade, p. 237-274. In I.R. Leal, M. Tabarelli \& J.M.C. Silva (eds.). Ecologia e conservação da Caatinga. Universitária da UFPE, Recife, Brazil.

Southwood, T.R.E. 1978. Ecological methods: with particular reference to the study of insect populations. Chapmann and Hall, London, England.

Underwood, E.C. \& B.L. Fisher. 2006. The role of ants in conservation monitoring: if, when, and how. Biol. Conserv. 132: 166-182.

Vasconcelos, H.L. \& J.M.S. Vilhena. 2006. Species turnover and vertical partitioning of ant assemblages in the Brazilian Amazon: a comparison of forests and savannas. Biotropica 38: 100-106.

Veloso, H.P., A.L.R. Rangel-Filho \& J.C.A. Lima. 1991. Classificação da vegetação Brasileira, adaptada a um sistema universal. IBGE, Rio de Janeiro, Rio de Janeiro, Brazil.

Wilkie, K.T.R., A.L Mertl \& J.F.A. Traniello. 2010. Species diversity and distribution patterns of the ants of Amazonian Ecuador. PLoS ONE 5: 1-5 (Also available online: www.plosone.org/article/ info\%3Adoi\%2F10.1371\%2Fjournal.pone.0013146). 